\title{
An Evaluation of The Relationship Between Family Stress And Job Stress Among Military Officers In Nigeria
}

\author{
${ }^{1}$ Anyaegbu, Dom Rowland ${ }^{2}$. Okoli, Paul Chibuike, $\mathrm{PhD}^{3}$. Ofojebe, Chukwuma, PhD, ${ }^{4}$. Ozougwu, Augustine \\ Obumneme, M.Sc. ${ }^{5 .}$ Eze, Boris Ejike ${ }^{6}$ Edoka Anthony Chukwunonye \\ 1. Department of Psychology, Enugu State University of Science and Technology Enugu-Nigeria. \\ 2. Department of Internal Medicine ESUT College of Medicine, Enugu State University of Science and Technology, Enugu-Nigeria. \\ ${ }^{3 .}$ Department of Psychology, Nnamdi Azikiwe University Awka-Nigeria. \\ ${ }^{4}$. Department of Internal Medicine ESUT College of Medicine, Enugu State University of Science and Technology, Enugu-Nigeria. \\ 5. Department of Psychology Enugu State University of Science and Technology, Enugu-Nigeria. \\ ${ }^{6}$. Department of Psychology, Nnamdi Azikiwe University Awka-Nigeria.
}

DOI: 10.29322/IJSRP.10.03.2020.p9910

http://dx.doi.org/10.29322/IJSRP.10.03.2020.p9910

\begin{abstract}
Background
This study investigated the relationship between family stress and job stress among military officers. The participants for this study comprised a total of 70 workers selected from 82 divisions Army Barrack located at Enugu Abakaliki Express Way Enugu comprising 60 male and 10 female officers. The participants were selected through the use of Convenience sampling technique. Their age ranged from $25-55$ years, with a mean age of 34.34 years and standard deviation of 5.34. The participants were selected across the three major tribes in Nigeria (Igbo, Hausa and Yoruba) and also from both Muslim and Christian religion. Participants that took part in this study were all married living with their spouses and have at least one child. Officers who have at least O'level certificates participated in the study. Instruments administered on them included Coping Skills, Job Related. Correlational design and Pearson Product Moment Correlation Coefficient Statistic was used to analyze the data collected. Result showed that the first hypothesis was not confirmed, there was significant relationship between family stress and job stress among Military Officers. This means that a significant relationship exists between family stress and job stress among Military Officers. Based on the above tested hypothesis there was a significant relationship between family stress and job stress among Military Officers. Therefore, based on these results, it was recommended that Military Officers and others should put a balance between their job and their family to avoid job interference with family and vice versa. The finding of this study should be guides to the Government when hiring Military Officers to know that work overload and things like that could lead to family stress thereby affecting the productivity of such ministry.
\end{abstract}

Index Terms- Family stress, job stress and military officers.

\section{INTRODUCTION}

Stress from time to time is an inevitable experience for all humans. This is because the modern life has brought with it not only innumerable means of comfort but also many demands that task human body. Thus, in this modern life characterized by fast changing world, no individual is free from stress. Military officers experience stress within and outside the family. Stress is the non-specific responses of the body to any demand placed upon it (Selye, 1956). Further, stress is any external event or internal drive which threatens to upset the organism equilibrium (Selye, 1956). Stress is one psychological reaction which occurs when people perceive an imbalance between the level of demand placed upon them and their capability to meet those demands (Kroemer \& Grandjean, 2001). Stressors on the other hand are regarded as problems requiring solution to which the family must adopt in order to maintain the functioning of the family system. Sources of stress include family relationships, occupation and how we think.

Family stress is a change in the family equilibrium and appraised by a person as taxing or exceeding her resources and endangering his/her well being (Lazarus \& Folkman, 1984). Family stress occurs when feedback indicated that the system does not have the requisite variety of rules to transform comfortably inputs into outputs that meet desirable standards (Burr \& Klein, 1994). Moreover, it occurs when family resources are threatened with costs, resources are actually cost and there is a failure to adequately gain resources following significant resources investment (Hobfoll, 1998). Similarly, it is that quality of experience, produced through a person-environment transaction that, through either over arousal or under arousal, results in psychological or physiological distress (Aldwin, 1994).

In Nigerian, family environment is entangled with stress and strains which directly affect homeosthesis. In the family, stressors not only refer to major life events but also long-term patterns of marital and family interaction that can affect the individual's ability to cope with stressful events. Examples of crisis events may include divorce, separation, death, illness of a family member, or a move to a new house or community (Mc Cubbin, Joy, Comean, Patterson \& Needle, 1980). Long-term interactive patterns which may result in family stress include the quality of marital and parent - child relationships, the nature of decision-making and problem solving, and existence of abusive relationships and behavioral problems (Mc Cubbin, et al. 1980). Family stress may also arise 
over time from significant changes in family roles and relationships associated with life cycle stages, such as the transition to parenthood, and empty nest period (Mc Cubbin et al., 1980).

The fore-most family related variable that has drawn the attention of most researchers on family stress is the number of children and the presence of very young children in the home have been associated with family role strain (Lero, 1992). This seems to imply that younger children generally require more attention from working parents and that more time is needed to spend on them. Similarly, the need to care for aging parents or other elderly relatives is becoming a reality for many parents today leaving many with the responsibility of caring for both children and parents (Duxbury \& Higgins, 1998). Given the rising cost of living over the past decade with no related increase in real family income, financial worries are reality for many families today. Financial hardship can be ongoing stressors in the family when individuals must face the challenges of providing for a family in uncertain economic times. In addition, the lack of monetary resources greatly reduces the coping options available to individuals in almost any stressful transaction as it can limit access to legal, medical, financial, or other professional assistance (Lazarus \& Folkman, 1984). Although neighbours and community provide an important means of social support, they also can increase the level of stressors in an individual's home environment. Neighbourhoods differ in the level of services they offer to individuals, such as access to recreation, shopping and entertainment facilities, or the availability of counseling services. They also differ in terms of orderliness, natural beauty, cleanliness, safety, transportation and road conditions (Matteson \& Ivanceviah, 1987). These among other factors could mete out stress to parents in the family.

However, Ali (2008) noted that work is an important part of an individual's life; it provides a source of income, helps to fulfill personal aims, builds social networks and serves communities, yet it is a major source of stress. Thus people in various professions experience different types of stress at different degrees (Asad \& Khan, 2003). Beehr (1981) defined occupational stress as a condition arising from the interaction of people and their jobs and characterized by changes within people and force them to deviate from their normal functioning. Cobb (1975) has the opinion that, the responsibility load creates severe stress among workers and managers. If the individual manager cannot cope with the increased responsibilities, it may lead to several physical and psychological disorders among them. Brook (1973) reported that qualitative changes in the job creates adjustment problem among employees. The interpersonal relationship within the department and between departments creates qualitative difficulties within the environmental demands and the response capability of the focal organism. Lazarus and Folkman (1984), also substantiated the discussion that stress will generate among human beings where a particular relationship between the person and environment, that is appraised by the person as taxing or exceeding his or her resources and endangering his or her well - being. The salience of job stress as a research area has been due in part to the magnitude of its effects. In addition to being associated with a variety of physical diseases including hypertension (O'Connor, White, \& Bundred, 2000; Tindall, 1998), high levels of job stress can have a negative effect on emotional well being (Pataniti, Niedhamman

Lang, \& Consoli, 2002). On the organizational level, high levels of job stress have been linked to low levels of productivity (Reynolds, 1997). In view of these controversies and dearth of empirical study on family stress among military officers in Nigeria, this present study looked at the relationship between family stress and job stress among military officers.

\section{Purpose of the Study}

The purpose of this study was to determine whether there will be statistical relationship between family stress and job stress among military officers.

Specifically, the aim was:

- To examine if family stress and job stress have any relationship among military officers in Enugu.

\section{Statement of the Problem}

The goal of every organization is to improve productivity on daily basis. This is to realize the goal and objectives of the organization and when this is not achieved, it has a lot of implications both to the employers and employees. It then becomes imperative to look into the employee's family life for optimal performance of their respective jobs. This is because, family stress and job stress may be important factors that may retard or enhance productivity in the military. This study therefore attempt to provide answer to this question:

- Will there be a statistical significant relationship between family stress and job stress among military officers in Enugu?

\section{Operational Definition of Terms}

Family Stress: This refers to a real or imagined imbalance between the demands on the family and the family's ability to meet those demands as measured by scores in Thomason and Havice (2009) Coping Skills for Families.

Job stress: This refers to a person's response to a stressor such as an office condition, workload, etc, as measured by scores in Kahn, Wolfe, Quinn, Snoek and Rosenthal (1964) Job-related Tension (JT).

Military Officers: Refer to some selected workers of 82 Division Enugu located at Enugu Abakaliki Express Way Enugu.

\section{METHOD}

\section{Participants}

A total of 70 workers selected from 82 divisions Army Barrack located at Enugu Abakaliki Express Way Enugu comprising 60 male and 10 female officers. Convenience sampling technique was applied to select the participants. Their age ranged from 25 - 55 years, with a mean age of 34.34 years and standard deviation of 5.34. The participants were selected across the three major tribes in Nigeria (Igbo, Hausa and Yoruba) and also from both Muslim and Christian religion. Participants that took part in this study were all married living with their spouses and have at least one child. Officers who have at least O'level certificates participated in the study.

\section{Instruments}


Two sets of instrument were adopted for the study. The first one was Thomason and Havice (2009) Coping Skills for Families and Kahn, Wolfe, Quinn, Snoek and Rosenthal (1964) Job Related Tension.

\section{Coping Skills for Families}

Coping Skills for Families Revised and Reviewed by Thomason and Havice (2009) is a 20-item inventory designed to a real or imagined imbalance between the demands on the family and the family's ability to meet those demands. The response format of the scale ranged from 1 (weak) to 5 (strong). The higher the response the more the family is coping with the family stressors. To validate the instrument as well as to establish its reliability, the researcher did a pilot study.

\section{Scoring}

The questionnaire has a direct scoring method i.e. 1 is scored as 1 and so on. The participants were instructed to place a check $(\sqrt{ })$ in the column that best described their status. Based on the scores reflected by the frequency of the items in the lives of the participants, they were classified into having family stress and coping with family stress using the median score as the point of discrimination.

\section{Reliability/Validity Test}

The scores obtained from the responses of the 20 officers selected from 103Batallion Gariki Awkunanaw Enugu was used and a test-retest reliability coefficient of .81 was obtained while face validity was adopted as the questionnaires were exposed to 3 experts in the department including the researcher's project supervisor for their scrutiny. Among the items in questionnaires include: our family does many things together and our roles in the family are shared.

\section{Job-Related Tension}

Is a 15-item inventory designed to assess the nature, causes and consequences of two aspects of organizational stress which is defined as the feelings of tension, discomfort, uncertainty, indecisiveness and distress that a worker experiences as a result of the social and physical circumstances of the work setting. The two components of organizational stress which the inventory assesses are: (a) Role conflict and (b) Role ambiguity. The inventory was developed by Kahn, Wolfe, Quinn, Snoek and Rosenthal (1964). The response format of the scale ranged from 1 (very dissatisfied) to 5 (very satisfied). The higher the response the more job satisfaction is indicated. The psychometric properties for Nigerian samples as provided by Oseghare (1998) are as follows:

\section{Samples}

Norms: The norms are the mean scores obtained by workers in the general population.

$\mathrm{M} \& \mathrm{~F}(\mathrm{n}=238), 2.81$

\section{Reliability/Validity}

Reliability was determined by the coefficient of alpha reported by Sheridan and Vredenburgh (1978) and Oseghare (1988) are .87 and .39 respectively.

A concurrent validity coefficient of .01 was obtained by correlating JT with rated performance (Sheridan et al. 1978) while
Oseghare (1988) obtained a coefficient of .46 when he correlated JT equivalent with Checklist Symptoms Stress by Kyriacou and Suteliffe (1978).

\section{Procedure}

The researcher introduced himself to the General Officer Commanding (GOC) 82-divisions Enugu through a letter of introduction from the Head, Department of psychology, Enugu State University of Science and Technology (ESUT). After rapport was established, the GOC approved the administration of the questionnaires. The participants responded to the two questionnaires in their offices and returned same to the researcher. On the whole, 125 copies of the two questionnaires each were administered to all the officers in their places of work. Out of this number, only 116 were completed and returned representing 92.8 percent return rate. Of this number also, eight (8) questionnaires were discarded for improper completion while 38 questionnaires were removed for not having both family stress and job stress as indicated by the test instruments and finally the remaining 70 questionnaires were used to analyze the data.

The tests were scored adding together the values of the numbers shaded in all the items. The Nigerian norms or mean scores are the basis for interpreting the scores of participants.

In Coping Skills for Families, scores higher than the norms also indicate adequate coping skills for families while scores lower than the norms indicate inadequate coping skills for families. Also in JT, scores higher than the norms indicate higher levels of job tension and stress while scores lower than the norms indicate the absence of organizational job stress.

\section{Design/Statistics}

This is a survey design and a Pearson Product Moment Correlation Coefficient was employed to analyze the data.

\section{RESULTS}

Table 1:

Summary table of Pearson product moment correlation coefficient on the relationship between family stress and job stress among Military Officers.

\section{Table of moment correlation}

Family Stress

(X) Job Stress (Y)

\begin{tabular}{llll} 
Family & \multicolumn{1}{c}{ StressPearson } & 1 & $.282^{*}$ \\
$(\mathrm{X})$ & Correlation & & .018 \\
& Sig. (2-tailed) & & 70 \\
& $\mathrm{~N}$ & 70 & 1 \\
Job Stress (Y) & $\begin{array}{l}\text { Pearson } \\
\text { Correlation }\end{array}$ & $.282^{*}$ & \\
& Sig. (2-tailed) & .018 & \\
& $\mathrm{~N}$ & 70 & 70 \\
\hline
\end{tabular}

*. Correlation is significant at the 0.05 level (2-tailed).

From the table above, r-calculated value of 0.282 is greater than r-critical value of 0.232 at $\mathrm{p}<.05$ indicating a significant positive relationship between family stress and job stress among 
Military Officer. Hence, the hypothesis which stated that "there will be no significant relationship between family stress and job stress among Military Officers" is hereby rejected. This means that a significant relationship exists between family stress and job stress among Military Officers. Based on the above tested hypothesis there was a significant relationship between family stress and job stress among Military Officers at $\mathrm{p}<.01$; indicating that family stress is related to job stress based on the fact that high score on family stress inventory indicate high score on job stress.

\section{DISCUSSION}

The finding of this study indicates that the hypothesis tested was not confirmed. The hypothesis that state: "there will be no significant relationship between family stress and job stress among Military Officers" was not confirmed. Rather, a significant positive relationship was observed between family stress and job stress among Military Officers. This means that family stress is linearly related to job stress based on the fact that family stress leads to job stress and vice versa. In other words, an increase in the family stress scores which indicates job stress will correlate positively with high scores on job stress. A positive correlation obtained in this situation is based on the fact that the participants scored high on family stress and high on job stress and vice versa. This disagrees with the findings of other researchers like Hauk and Chodkiewicz (2013) who found that both general and occupational stresses were not significant mediators in the relationship between workaholism recognized as a behavioural tendency and the conflicts described. Also, there was no difference between female physicians working full-time or reduced hours in regard to work interfering with family or family interfering with work (Carr, Gareis, \& Barnett, 2003).

The finding of this study was in line with this study, thus in a study by Alexandros-Stamatios, Matilyn and Cary (2003), it questions whether the workers have to take work home, or inability to forget about work when the individual is at home. Home-work interface is important for the workers to reduce the level of work-related stress. A common finding is that work stress has negative effects on families and home life (Muchinsky, 2000). Robinson, Flowers, and Carroll (2001), for example, reported that work stress negatively affects marital cohesion. In addition, Crouter and Bumpus (2001) highlighted the negative spillover effect of work stress into family life. They reported that work stress has detrimental implications on the quality of family interactions. Work interfering with family had a direct relationship with work exhaustion in a 4-year study of medical technologists, 80 percent of whom were female (Blau, Tatum, \& Ward-Cook, 2003). Family interfering with work, however, was not studied. A study of 101 female nurses found that work interfered with family more than family interfered with work (Gottlieb, Kelloway, \& Martin-Matthews, 1996). The investigators noted, however, that most of the nurses, who were in their mid-40s, were between the demands of child care and elder care. This finding is consistent with findings from a study of 170 Australian nurses: the principal determinant of stress was workload; nurses were unlikely to bring personal stress to work (Bryant, Fairbrother, \& Fenton, (2000).

Work-family conflict is a form of inter role conflict in which role pressures from work and family domains become an obstacle to employees' job performance. In study by Ogbogu (2013) using
250 randomly selected female academic staff from 3 purposively selected Public Universities in Southern Nigeria. Results revealed that several factors such as long hours of work, overcrowded job schedules, inadequate working facilities, family and domestic responsibilities, teacher-student ratio and cohesive Heads of Departments accounted for greater work family conflict. It was also found that women's experiences of work-family conflict impacted negatively on their level of job performance and well-being.

In another study that examined the main and interaction effects of work-family conflict and job stress on job burnout among working mothers in post-consolidation banks in Nigeria. Using a randomly selected sample of 311 working mothers, Balogun (2014) results showed that work-family conflict and job stress had a significant main and interaction effects on overall job burnout and its three dimensions. Finally, the result of this study implies that Military Officers' family stress level affects their job stress.

\section{Implications of the Findings}

The implication of the above findings is that since the null hypothesis stated was disconfirmed, Military Officers and others should put a balance between their job and their family to avoid job interference with family and vice versa. Again, eustress is good for people to function well in their job but when it turns to distress it may bring about family stress and or job stress.

The finding of this study should be guides to the Government when hiring Military Officers to know that work overload and things like that could lead to family stress thereby affecting the productivity of such ministry. Theoretically, the finding of this study will be a useful contribution to the existing body of knowledge in the areas of job/family.

\section{Limitations of the Study}

The size of the population used is a factor that may affect the generalization of the finding of this study to a large population. Other variables such as; job commitment, payment package, hours spent on job, role conflict, etc., and should be studied in relation to family stress. Despite the level of rapport, and confidentiality generated before administering the tests, some difficulties were encountered. They involve: production of the questionnaires and getting the attention of some of the Military Officers because of the nature of their work.

\section{Suggestions for Further Research:}

Hence, further research on this study should try and find out other factors not studied in this research on family stress and job stress among Military Officers such as:

To sample Military Officers in other Barracks and States; to study more on the influence as well as the relationship between the variables in this study; to sample workers in other professions like hospital workers (Doctors/Nurses), University lecturers, bank workers and to sample larger population and also large sample size, etc.

\section{SUMMARY AND CONCLUSION}

Military Officers and others should continually seek the therapeutic advice of Military psychologists to know the factors 
responsible for being happy and healthy on the job. Again, offices as well as other ministries that recruit workers should also start employing psychologists to work in their ministries/organizations to be in charge of worker's psychological well-being while boosting productivity.

\section{Compliance with Ethical Standards Conflict of interest:}

All authors declare that they have no conflict of interest. All participants filled the consent form to declare their free will to participate in the study. Again, this study was not funded by any person, group or organization.

\section{REFERENCES}

[1] Aldwin, C. M. (1994). Stress, coping and development: An integrative perspective. New York: The Enilford Press.

[2] Alexandros-Stamatios, G. A., Matilyn, J.D., \& Cary, L.C., (2003). Occupational Stress, Job satisfaction, and health state in male and female junior hospital doctors in Greece, Journal of Managerial Psychology, 18(6), 592-621.

[3] Ali, A. (2008). A comparative study between white - collar and blue - collar professionals and job stress levels. Bliahria Journal of Professional Psychology, 4, 55-68.

[4] Angell, R. C. (1986). The family encounters the depression Gloucester, M. A. Peter Smith.

[5] Asad, N. \& Khan, S. (2003). Relationship between job stress and burnout: Organizational support and creativity as predictor variables. Pakistan Journal of Psychological Research, 18 (3-4), 139-149.

[6] Balogun, A.G. (2014). Job burnout among working mothers in Nigeria postconsolidation banks: Effects of work-family conflict and job stress. International Journal of Research Studies in Psychology, 3(5), 27-36.

[7] Beehr, T. F. (1981). Work-Role Stress and Attitudes toward Co-workers. Group and Organization Studies 6, 2, $201-10$.

[8] Blau, G., Tatum, D.S., \& Ward-Cook, K. (2003). Correlates of work exhaustion for medical technolgists. Journal of Allied Health, 32:14857.

[9] Bryant, C., Fairbrother, G., \& Fenton, P. (2000). The relative influence of personal and workplace descriptors on stress. British Journal of Nursing, $\quad 9(13): 876-80$.

[10] Burr, W. R., \& Klein, S. R. (1994). Re-examining family stress. Thousand Oaks, C. A. Sage.

[11] Carr, P.L., Gareis, K.C., \& Barnett, R.C. (2003). Characteristics and outcomes for women physicians who work reduced hours. Journal of Women's Health, 12:399-405.

[12] Crouter, A.C., \& Bumpus, M.F. (2001). Linking parents' work stress to children's and adolescents' psychological adjustment. Current Directions in Psychological Science, 10, 156-159.

[13] Duxbury, L. \& Higgins, C. (1998). Work-life balance in Saskatchewan: Realities and challenges, Saskatoon: Government of Saskatchewan.

[14] Gottlieb, B.H., Kelloway, E.K., \& Martin-Matthews, A. (1996). Predictors of work-family conflict, stress, and job satisfaction among nurses. Canadian Journal of Nursing Research, 28(2):99-117.

[15] Hauk, M. \& Chodkiewicz, J. (2013 )The role of general and occupational stress in the relationship between workaholism and workfamily/family-work conflicts. International Journal of Occupational Medicine and Environmental Health. 26(3):383-93

[16] Hill, R. (1958). Generic features of families under stress. Social Casenasic, $49,139-150$

[17] Hobfoll, S. E. (1998). Stress ensures culture and community. The Psychology and Philosophy of stress. New York: Plenum.

[18] Hobfoll, S. E., Lily, R. S. \& Jackson, A. P. (1992). Conservation of social resources and the self. In H. O. F. veil and U. Baymann (ed), the meaning and measurement of social support (125-142). Hemisphere Washinton D. C.

[19] Kahn, R.L. Wolfe, D.N. Quim R.P. Snoek, J.D \& Rosenthal. R. (1964). Organizational stress: studies in role conflict and ambiguity. New York: Wiley.
[20] Koos, E. L. (1946). Families in trouble. Moringside Heights, NY: King's Crown.

[21] Kroemer, K. H. E. \& Grandjean, E. (2001). Fitting the task of the human. A textbook of occupational ergotmonics, fifth edition, Taight and Francis Limited, 211-215.

[22] Kyriacou, C. \& Sutcliffe, J. (1978). Teacher stress: Prevalence, sources and symptoms. British Journal of Educational Psychology, 48, 159-167.

[23] Lazarus, R. S. \& Folkman, S. (1984). Stress, appraised and coping. New York: Springer.

[24] Lero, D. (1992). Parental work and child care needs, Ottawa: statistics Canada, Catalogue, 259-529.

[25] Matteson, M. \& Ivanceviah, J. (1987). Controlling work stress effective human resource and management strategies. San Francisco: Jossey - Bass.

[26] McCubbin, H., Joy, C., Canble, E., Comean, J., Patterson, J. \& Needle, R (1980). Family stress and coping: A decade review. Journal of marriage and the family, 855-871.

[27] Minuchin, S. (1974). Families and family therapy. Cambridge, M. A: Harvard University Press.

[28] Muchinsky, P. M. (2000). Psychology applied to work (6th ed.). Belmont, CA: Wadsworth/Thomson Learning.

[29] O'Connor, M.J; O' Connor, S. White, O. P \& Bundred, R. (2000). Should employers worry? Workplace Stress Claims following the John Walker Decision, Personnel Review 30(4), 468-487.

[30] Ogbogu, C.O. (2013). Work-Family role conflict among academic women in Nigerian Public Universities. The West East Institute International Academic Conference Proceedings Orlando, USA

[31] Oseghare, C. K. (1988). An evaluation study of McLean's stressors checklist. Unpublished M.Sc. Research Project. Department of Psychology, University of Lagos.

[32] Petarnite, S.O. Nieddhammer, O; Lang, \& Consoli T.H. (2002). Work stress, control Beleifs and Well - being in Differences between the PRC and Taiwari, Journal of Managerial psychology. 18(6), 479-510.

[33] Reynolds, S. (1997). Psychological well-being at work: Is prevention Better than cure? Journal of psychosomatic research, 43(1),93-102.

[34] Robinson, B. E., Flowers, C., \& Carroll, J. (2001). Work stress and marriage: A theoretical model examining the relationship between workaholism and marital cohesion. International Journal of Stress Management, 8, 165-175.

[35] Selye, H. (1956). The Stress of Life. New York: McGraw-Hill.

[36] Sheridan, J. E. \& Vredenburgh, D. J. (1978). Usefulness of leadership bahaviour and social power variables in predicting job tension, performance and turnover of nursing employees. Journal of Applied Psychology, 63, 89. 95.

[37] Steers, R.M. (1981). Emotional exhaustion on a high stress organization Academy of management journal, 26, 567-586.

[38] Thomason, D. J., \& Havice, P. A. (2009). "Stress on the Farm Home Study Course". Developed by Iowa State Cooperative Extension and the "Farm Family Stress" series developed by Michigan State Cooperative Extension Service. Clemson University Cooperating with U. S. Department of Agriculture and South Carolina Counties.

[39] Tindall, C.T. (1998). Measuring job stressors and studying the health impact of the work environment: An epidemiological commentary. Journal of occupational health psychology, 3, 390-401.

\section{AUTHORS}

First Author - Anyaegbu, Dom Rowland, Department of Psychology, Enugu State University of Science and Technology Enugu-Nigeria.

Second Author - Okoli, Paul Chibuike, PhD, Department of Internal Medicine ESUT College of Medicine, Enugu State University of Science and Technology, Enugu-Nigeria.

Third Author - Ofojebe, Chukwuma, PhD, Department of Psychology, Nnamdi Azikiwe University Awka-Nigeria.

Fourth Author - Ozougwu, Augustine Obumneme, M.Sc, Department of Internal Medicine ESUT College of Medicine, 
Enugu State University of Science and Technology, EnuguNigeria.

Fifth Author - Eze, Boris Ejike, Department of Psychology Enugu State University of Science and Technology, EnuguNigeria.
Sixth Author - Edoka Anthony Chukwunonye, Department of Psychology, Nnamdi Azikiwe University Awka-Nigeria. 